\title{
Shariah Disclosure Practices in Malaysian Islamic Banks using the Shariah Disclosure Index
}

\author{
Nur Afiqah Md Amin \\ International Islamic University Malaysia, Malaysia, afiqahamin@gmail.com
}

Noraini Mohd Ariffin

International Islamic University Malaysia, Malaysia

Corresponding email: norainima@iium.edu.my

A. H. Fatima

International Islamic University Malaysia, Malaysia, afatima@iium.edu.my

Article History

Received: October $5^{\text {th }}, 2020$ | Revised: January 23 ${ }^{\text {rd }}, 2021$ | Accepted: March $6^{\text {th }}, 2021$

\begin{abstract}
Islamic banks are required to ensure their operations and activities comply with the Shariah principles. According to Islamic Financial Services Act (2013) in Malaysia, all operations and activities of Islamic financial institutions including Islamic banks have to comply with decisions made by the Shariah Advisory Council (SAC) of Bank Negara Malaysia (BNM) and the Shariah Committee (SC) of the Islamic financial institution to ensure Shariah compliance. In practice, Shariah compliance is considered a crucial factor by bank stakeholders, especially Muslim customers in their decision to use Islamic financial products. Thus, one of the ways for Islamic banks to convey their Shariah-compliance to their stakeholders is through annual reports. This study examines the level of compliance on Shariah disclosure in the annual reports of Malaysian Islamic banks. A Shariah disclosure index, comprising mandatory and voluntary items, was developed from Bank Negara Malaysia (BNM) guidelines and Accounting and Auditing Organization for Islamic Financial Institutions (AAOIFI) standards. Shariah disclosure data were collected from the annual reports for the year 2016 of the 16 Islamic banks in Malaysia. Based on Institutional Theory, this study hypothesised high compliance, however the results revealed that none of the banks had full compliance to the mandatory items. Nevertheless, some of these banks disclosed voluntary items. The findings provide useful insights to the regulators and stakeholders on Islamic banks' compliance on Shariah disclosure. The study also reveals the importance of disclosing additional items in the annual reports of Islamic banks.
\end{abstract}

Keywords: Shariah disclosure, Islamic banks, Malaysia

JEL Classification: M40, G21, E58

Type of paper: Research Paper

@ IJIEF 2021 published by Universitas Muhammadiyah Yogyakarta, Indonesia All rights reserved

DOI:

Web:

https://doi.org/10.18196/ijief.v4i0.9953 https://journal.umy.ac.id/index.php/ijief/article/view/9953

\section{Citation:}

Amin, N. A. M., Ariffin, N. M., \& Fatima, A. H. (2021). Shariah disclosure practices in Malaysian Islamic banks using the shariah disclosure index. International Journal of Islamic Economics and Finance (IJIEF), 4(SI), 63-86. DOI: https://doi.org/10.18196/ijief.v4i0.9953. 
Amin, Ariffin, \& Fatima $\mid$ Shariah Disclosure Practices in Malaysian Islamic Banks using the Shariah Disclosure Index

\section{Introduction}

Islamic banks are required to ensure that their operations and activities comply with the Shariah principles. However, in some cases, Islamic banks may inadvertently digress from the Shariah due to the lack of rules and regulations on contemporary transactions (Ullah, 2014). In order to alleviate this problem, Bank Negara Malaysia (BNM) issued the Shariah Governance Framework guidelines in 2010, which has been superseded by Shariah Governance Policy Document (2019). In 2013, the Islamic Financial Services Act (IFSA) was enacted to regulate Islamic financial institutions (IFIs) in Malaysia. This Act reinforced the importance of Shariah compliance, i.e. all operations of the IFIs and contracts offered by the IFIs must comply with the Shariah. Specifically, the Islamic banks must ensure that they are free from any form of interest (riba), uncertainty (gharar) and any activities that involve gambling (maysir), and also activities that cause harm to the society.

Shariah compliance is deemed crucial, especially for Muslim customers, in deciding to use Islamic banks' services (Ashraf \& Lahsasna, 2017). Therefore, it is vital for Islamic banks to communicate their Shariah compliance to stakeholders. A channel of communication between Islamic banks and their stakeholders is annual reports. As the foundation of an Islamic bank is closely tied to religion (Haniffa and Hudaib 2007), transparent disclosure on Shariah compliance in its annual reports enhances the credibility of its business operations, promotes the bank's accountability and reputation, consequently increasing customers' confidence.

Disclosure practices of listed companies are usually regulated. Similarly, BNM regulates financial institutions in Malaysia; hence it issued "Financial Reporting for Islamic Banking Institutions" in 2016 (revision issued in 2019). Although issued as guidelines, the reporting requirements are considered mandatory for Islamic banks because BNM is their regulatory authority. Therefore, Islamic banks in Malaysia must disclose the items required by these guidelines. It must be noted that since Malaysia has adopted the Financial Reporting Standards (FRS) issued by the International Accounting Standards Board (IASB), BNM supports compliance with these standards. Therefore, BNM's reporting requirements for Islamic banks are conceptually in line with the FRS. Consequently, the general basis of these guidelines is to provide information that is useful to stakeholders, particularly investors and creditors of Islamic banks, as recommended by the "Conceptual Framework for Financial Reporting" (IASB, 2018). However, as the guidelines were revised in 2019, the extent of disclosure based on mandatory guidelines by BNM has not been examined. Moreover, in line with providing useful information, Islamic banks are recommended to make voluntary disclosure, in addition to mandatory disclosure. 
Amin, Ariffin, \& Fatima $\mid$ Shariah Disclosure Practices in Malaysian Islamic Banks using the Shariah Disclosure Index

This study attempts to examine the level of compliance on Shariah disclosure in Islamic banks' annual reports, which includes both mandatory and voluntary disclosure. Shariah disclosure is important to convince stakeholders of Islamic banks that these banks are indeed Shariah compliant in all aspects of their activities. Shariah disclosure would strengthen the credibility of the products and services offered by the Islamic banks and substantiate that they are indeed different from conventional banks.

The identity of banks as being "Islamic" is encapsulated in the fact of their being Shariah complaint. Islamic banks have to constantly reassure their stakeholders, especially their depositors and customers of the fact that they are indeed Islamic in order to attract and keep these customers. This is because the banking sector is extremely competitive and being Islamic is a niche that attracts the Muslim customers to these banks. Should these banks fail to adequately convince their customers, there are several other competing Islamic banks to choose from. One of the ways to validate their Shariah compliance is to provide such details through disclosure in their annual reports. These reports would be referred to by informed customers and they in turn would relay interesting and important information to their relatives and friends. Therefore, the importance of conveying the fact that they are Shariah compliant to their stakeholders, should not be underestimated by Islamic banks.

Due to Shariah compliance being the fundamental aspect of these banks, BNM has issued guidelines to assure stakeholders of this fact. Consequently, disclosure of such information has become mandatory, hence noncompliance could result in penalties on these banks. However, a recent study that specifically focuses on Shariah disclosure by Islamic banks in Malaysia, in reference to BNM guidelines and AAOIFI standards, in particular has been lacking. Thus, in addition to helping Islamic banks to provide assurance of their identity, retain customers, and generate findings beneficial to regulators, this study attempts to extend the literature on Shariah disclosure.

The organization of the paper is as follows: Section 2 comprises the background, development and relevant regulations in relation to Islamic banking in Malaysia. Relevant prior studies are also reviewed in this section. Furthermore, there is a discussion on Institutional theory, which is referred to in framing the hypothesis of this study. Section 3 covers the method and data used in this study. Section 4 discusses the analysis of results and findings of this research. Lastly, Section 5 concludes this study with a summary of the findings, recommendations and limitations of the research. 
Amin, Ariffin, \& Fatima $\mid$ Shariah Disclosure Practices in Malaysian Islamic Banks using the Shariah Disclosure Index

\section{Literature Review}

\subsection{History and Concepts of Islamic Banking}

Historically, the first Islamic financial institution in Malaysia was the Muslim Pilgrimage Saving Corporation (Lembaga Tabung Haji), which was established in 1963. In 1969, this corporation transitioned into Tabung Haji, which primarily is a savings for Muslims to perform their pilgrimage. Tabung Haji makes Shariah compliant investments with the funds, i.e. free of riba (interest). The success of Tabung Haji led to the establishment of Bank Islam Malaysia Berhad (BIMB) by the Malaysian government, in 1983. BIMB was the first full-fledged Islamic commercial bank in Malaysia (Ariff, 1988). Next, Bank Muamalat Malaysia Berhad was established in 1999. Since then, conventional banks started offering Islamic products and services through Islamic windows, and foreign full-fledged Islamic banks started operations in Malaysia. The Islamic windows later became subsidiaries of conventional banks. From humble beginnings, Islamic banking has grown to become an important component in the Malaysian financial system, contributing significantly to the Malaysian economy (Islam, Ahmed \& Abdul Razak, 2015).

Five features distinguish Islamic banks from conventional banks (Haniffa and Hudaib, 2007). The first feature is the underlying philosophy of Islamic banks being Shariah compliant. As Islamic banks are entrusted with investing depositors' and shareholders' funds in line with the Shariah, they are accountable to communicate their compliance to stakeholders in their annual reports. Secondly, to avoid interest-based products, Islamic banks provide profit and loss-based products, such as Mudharabah and Musharakah. Therefore, transparency on these products' details is crucial to the stakeholders. Moreover, Islamic banks inadvertent involvement in nonpermissible activities, for example activities with uncertainty (gharar) should be fully disclosed to stakeholders through annual reports.

In addition, Islam emphasises social justice, therefore, Islamic banks are expected to be socially accountable by providing zakat (alms), charity and qard (benevolent loan). As zakat is compulsory in Islam, details on zakat, such as the amount of zakat distributed, zakat payable, and the beneficiaries are crucial to be reported to stakeholders. Furthermore, details on Islamic banks' social contributions such as charity and qard, specifically sources and the usage of qard fund would be warranted by stakeholders. Thus, information on zakat, charity and qard should be reported by Islamic banks in their annual reports. 
Amin, Ariffin, \& Fatima $\mid$ Shariah Disclosure Practices in Malaysian Islamic Banks using the Shariah Disclosure Index

The final difference between Islamic and conventional banks is the former has a Shariah Supervisory Board, or Shariah Committee in the case of Malaysia. This committee is an internal control mechanism that ensures all operations and business transactions are in line with the Shariah. Therefore, Islamic banks should disclose details regarding the competence of their Shariah committee to boost public confidence on the Shariah compliance of their operations. After providing a brief narrative on the history and nature of operations of Islamic banking, the next section proceeds with relevant Islamic banking regulation.

\subsection{Islamic Banking Regulation}

In Malaysia, a new legislation was introduced in 2013 that governs and strengthens the regulations on Shariah compliance in Islamic financial institutions. This legislation is the Islamic Financial Services Act (IFSA) 2013. Before that, the Islamic banks were governed by the Islamic Banking Act 1983. IFSA 2013 replaced the prior act by imposing more stringent regulation in which more penalties will be charged on the Islamic banks including takaful 1 institutions that do not comply with the Shariah requirements. Generally, this act provides regulatory requirements in terms of supervision of Islamic financial institutions, payment systems, and other relevant activities to enhance the financial stability and compliance with the Shariah (IFSA, 2013). It is mandatory for Islamic banks to adhere to IFSA 2013, thus compliance with this regulation provides added assurance of Islamic banks' Shariah compliance.

However, Islamic banks should not only comply with the Shariah, but report this compliance to their stakeholders. Thus, in relation to financial reporting, the Guidelines on Financial Reporting for Licensed Islamic Banks (GP8-i) is the first reporting guideline issued by BNM for Islamic banking institutions. This guideline was issued in August 2003 for Islamic banks' annual accounts commencing in 2004. The latest revised guidelines on financial reporting for Islamic banks were issued on 27 September 2019, namely the "Financial Reporting for Islamic Banking Institutions". It clarifies and sets the specific requirements on the application of Malaysian Financial Reporting Standards (MFRS). This guideline focuses on providing the basis for presentation and disclosure of Islamic banks' financial statements on financial performance of the banks, as well as their Shariah and MFRS compliance (BNM, 2019). This guideline aims to ensure consistency and comparability of financial statements of Islamic banks in complying with the provisions of the Companies Act 2016, approved accounting standards and Shariah requirements.

\footnotetext{
${ }^{1}$ Takaful can be likened to Islamic insurance.
} 
Amin, Ariffin, \& Fatima $\mid$ Shariah Disclosure Practices in Malaysian Islamic Banks using the Shariah Disclosure Index

\subsection{Previous Studies}

\subsubsection{Islamic Banks' Compliance with Accounting Standards}

Iqbal, Ahmad and Khan (1998) listed the complex institutional aspects and structural requirements for Islamic banks to be competitive as well as to prosper within the banking sector. One of the major challenges is to develop uniform regulations among Islamic banks around the world. This is because the banks might have different theories and practices (Siddiqi, 2006) in addition to different countries adhering to different accounting standards or guidelines.

According to Sole (2007), two institutions were established to achieve international consistency; the first institution is the Accounting and Auditing Organization for Islamic Financial Institutions (AAOIFI), which was established in 1991 and based in Bahrain. AAOIFI is primarily responsible for the development and issuance of standards for the global Islamic finance industry. It issues the Shariah, accounting, auditing, ethics, and governance standards for Islamic financial institutions. The second institution is the Islamic Financial Services Board (IFSB). It is an international standard setter that promotes the stability of Islamic financial services industry by issuing standards and guidelines for banking, capital market, and insurance industry.

A number of prior studies examined Islamic banks' compliance with AAOIFI standards in the Middle East. Sarea and Hanefah (2013) distributed questionnaires to 312 accountants of Islamic banks in Bahrain. Similarly, Shatnawi and Al-bataineh (2013) distributed questionnaires to the accountant, chief accountant, financial manager, division manager, auditor, and vice president of Jordan Islamic Bank branches located in Irbid, Madaba, and Mafraq. Both studies found commitment to compliance with AAOIFI standards. Specifically, Sarea and Hanefah's (2013) results indicated that the Islamic banks in Bahrain were in full convergence to AAOIFI accounting standards. Since AAOIFI accounting standards are mandatory in Bahrain, findings of high level of compliance with these standards was expected. Shatnawi and Al-Bataineh's (2013) findings also revealed that the Jordan Islamic Bank was committed to compliance with AAOIFI standards.

Later, Ahmad and Daw (2015) examined compliance of Fashlowm Islamic branch of the Gumhouria Bank (the biggest bank in Libya) with AAOIFI's guidelines. In addition to questionnaires, the study used content analysis of annual reports from 2010 to 2013. The results of this study indicated that the compliance level was low during the early years at $30.4 \%$, which was 
Amin, Ariffin, \& Fatima $\mid$ Shariah Disclosure Practices in Malaysian Islamic Banks using the Shariah Disclosure Index

inconsistent with the results in Sarea and Hanefah (2013). However, the level of compliance increased over the period of study, reaching $47.4 \%$ in 2013.

Unlike the studies before, Ajili and Bouri (2017) compared the level of compliance of 39 Islamic banks in Gulf Cooperation Council (GCC) states with the disclosure requirements of AAOIFI and International Financial Reporting Standards (IFRS). Their findings showed that although 23 banks complied with AAOIFI and 16 banks complied with the IFRS, the level of compliance with IFRS was higher than the level of compliance with AAOIFI.

Subsequent to a brief review of relevant literature on compliance of Islamic banks to accounting standards, the next section discusses the importance of disclosure, in general, in the banking sector and particularly in Islamic banks. Then, the following section proceeds to the literature on Shariah disclosure in Islamic banks.

\subsubsection{The Importance of Reporting in Islamic Banking Sector}

Reporting through disclosures is the means to communicate with stakeholders, hence information disclosure is needed to ensure the effective allocation of resources in a society (Adina \& Ion, 2008) and reduce the problem of information asymmetry between the managers and external users (Verrecchia, 2001; Healy \& Palepu, 2001).

Huang (2006) justified the importance of disclosure in the banking sector. Firstly, the usefulness of accounting reports in stakeholders assessing the performance of banks. Secondly, as risks and cash are paramount in banks, their performance cannot be solely evaluated by earnings. Lastly, stakeholders need to know the breakdown of items as aggregated figures are less informative. Moreover, the increasing complexity of the financial environment and diversity of information required by users (Frolov, 2007) have driven more quantitative and qualitative disclosures, including in banks.

Islam could influence accounting measures and disclosure of Islamic banks (Baydoun and Willet, 2000). Specifically, two important criteria for disclosure in Islamic accounting are social accountability and full disclosure (Haniffa \& Hudaib, 2002; Baydoun \& Willet, 2000). As a khalifah, accountability to Allah ultimately, encompasses accountability to other creations. Therefore, accountants and managers are also accountable to the society and will be judged in the hereafter (Maali, Casson \& Napier, 2006). The Qur'an states: "God takes careful account of everything" (Qur'an, 4:86). This short phrase from the Qur'an is a reminder that each human being, including preparers of Islamic banks' annual reports, will be answerable for their deeds on earth on the Day of Judgement. Therefore, based on Haniffa and Hudaib (2002), 
Amin, Ariffin, \& Fatima $\mid$ Shariah Disclosure Practices in Malaysian Islamic Banks using the Shariah Disclosure Index

disclosing useful information is one of the ways for these preparers to discharge their accountability to their stakeholders.

Baydoun and Willet (2000) explained that full disclosure means disclosing useful information to the public in accordance with the principles of Shariah, instead of disclosing everything. Similarly, according to Haniffa and Hudaib (2002), social responsibility and full disclosure emphasise on the disclosure of relevant and faithfully represented information that will assist users in making both economic and religious decisions, simultaneously enable management and accountants in fulfilling their obligations to Allah and ummah.

\subsubsection{Shariah Related Disclosure}

Although there are several disclosure studies on Islamic banks, literature specifically related to Shariah disclosure is limited, albeit growing. For example, other than Paino, Bahari, and Bakar (2011) who studied Shariah reporting in Islamic banks in Malaysia, Wan Abdullah, Percy, and Stewart (2013) examined the extent of disclosure on Shariah Supervisory Boards (SSB) in Malaysian and Indonesian Islamic banks. As SSB oversees Shariah compliance, the disclosure on SSB is deemed as Shariah related. Later, Ramli et al. (2015) broadens their study's scope to Shariah Governance.

Paino et al. (2011) developed a Shariah disclosure index based on the guidelines issued by BNM. Their index items include performance overview and statement of corporate governance, role and responsibilities of Shariah Advisory Council (SAC), zakat obligations and zakat amount. They performed a content analysis of the 2009 and 2010 annual reports for 17 Islamic banks in Malaysia. They found that, overall, the score of compliance was $94.7 \%$ on average. Only 7 items scored $100 \%$. The Chi-square test indicated that there was no significant difference in the level of Shariah disclosure among Islamic banks in Malaysia.

As mentioned above, Wan Abdullah et al. (2013) focused only on disclosure in relation to SSB. They analysed the content of annual reports for 2009 of 19 and 6 Islamic banks in Malaysia and Indonesia, respectively. An SSB index was developed by reviewing SSB disclosure practices literature, AAOIFI governance standards, IFSB's corporate governance guidelines, and local Malaysian and Indonesian guidelines and regulations. The items in the index encompass SSB members' background, SSB'S duties, responsibilities and activities, SSB report and SSB remuneration. The results indicate that there was still limited disclosure on SSB as only 4 banks disclosed more that $50 \%$ of the SSB index items. Their findings suggest a need for higher level of disclosure on SSB in order to demonstrate greater accountability. 
Amin, Ariffin, \& Fatima $\mid$ Shariah Disclosure Practices in Malaysian Islamic Banks using the Shariah Disclosure Index

Ramli et al. (2015) developed a Shariah Governance index from the BNM guidelines. The index contained governance items on board of directors, Shariah supervisory board, internal Shariah review, Shariah audit, Shariah risk management, Shariah research, management and Shariah secretariat. Data were collected using content analysis of 2012 annual reports of 7 Islamic financial institutions which were randomly picked from the list of licensed Islamic banks from BNM website. Their results indicated that Maybank Islamic Berhad (MIB), Bank Islam Malaysia Berhad (BIMB), and Bank Muamalat Malaysia Berhad (BMMB) had the most Shariah Governance disclosure, respectively. Furthermore, there was higher disclosure on items related to Board of Directors and SSB, whereas disclosure related to Shariah research was low.

Based on the review of the literature above, it is evident that literature on Shariah related disclosure exists. However, since then, there have been new regulatory requirements in relation to Shariah disclosure. Hence, due to these requirements, failure to disclose would be tantamount to non-compliance, which could result in certain penalties for the Islamic banks. Thus, this study determines the extent of Shariah disclosure by Islamic banks in Malaysia subsequent to updated regulatory requirements.

\subsection{Institutional Theory and Hypothesis}

In relation to the Islamic banks' context, Islamic banks face pressures from BNM because there are many regulations that they need to comply with. These regulations are the Shariah Governance Framework (2010), which has been superseded by Shariah Governance Policy Document (2019) Islamic Financial Services Act (2013), and Financial Reporting for Islamic Banking Institutions (revised in 2019). In addition, Islamic banks need to deal with indirect pressures from society's expectations. In terms of reporting, if Islamic banks comply with authority imposed Shariah reporting rules, they will have no problems with authorities. This should validate the legality of their operations, thus differentiate them from conventional banks, consequently attracting customers.

This study specifically uses Coercive isomorphism of Institutional Theory to develop the hypothesis. Prior literature found that coercive pressures, for example from the World Bank, enhances environmental disclosure (Rahaman, Lawrence, \& Roper, 2004). Moreover, institutional pressure improves the quality of circular economy accounting information disclosure by Chinese listed companies (Wang et al., 2014). In addition, prior studies found that regulation would coerce management to strictly follow rules leading to homogeneity among firms (Carpenter and Feroz, 2001). This is supported by 
Amin, Ariffin, \& Fatima $\mid$ Shariah Disclosure Practices in Malaysian Islamic Banks using the Shariah Disclosure Index

Paino et al. (2011) who found that there was no significant difference in the level of Shariah disclosure among Islamic banks in Malaysia.

In the context of this study, based on Institutional Theory, BNM regulations would coerce Islamic banks to comply with the reporting requirements; hence compliance level on Shariah disclosure is expected to be high among Islamic banks in Malaysia. The pressure is more severe as enforcement action may be taken if the banks fail to disclose. Furthermore, extending prior literature, there should be minimal variation of Shariah disclosure in the annual reports of Islamic banks. Therefore, the hypothesis of this study is: The compliance level of Shariah disclosure is high among Islamic banks in Malaysia.

\section{Methodology}

\subsection{Data}

This study uses secondary data from the annual reports for the year 2016 of all 16 commercial Islamic banks in Malaysia, which are listed by BNM. There are various Islamic financial institutions in Malaysia, including commercial Islamic banks, development financial institutions, investment banks, and takaful operators. However, this study only focuses on the population of commercial Islamic banks.

The 2016 annual reports were the latest available annual reports at the time of data collection. These annual reports were accessible from each bank's website. The Shariah disclosure in the annual reports were measured using an index, thus its development is discussed next.

\subsection{Model Development of Shariah Disclosure Index}

A Shariah disclosure index was developed to measure the level of compliance. A disclosure index is a checklist of items that companies would potentially disclose (Paino et al., 2011) as it comprises either mandatory or voluntary items, or both. Therefore, this study's 31 mandatory items were a compilation of Shariah disclosure requirements from BNM's Financial Reporting for Islamic Banking Institutions guideline, whereas the 5 voluntary items were added from the AAOIFI standards. Thus, the index has 36 Shariah disclosure items in total, grouped into 5 categories as shown in Table 1. 
Amin, Ariffin, \& Fatima $\mid$ Shariah Disclosure Practices in Malaysian Islamic Banks using the Shariah Disclosure Index

Table 1. Number of Items in Each Category

\begin{tabular}{lcc}
\hline \multicolumn{1}{c}{ Category } & Mandatory Item No. & Voluntary Item No. \\
\hline Financing, deposit \& investment & $1-6$ and 9 & $7,8,10,11$ \\
Zakat and charity & $13-20$ & 12 \\
Shariah non-compliance activity & $21-26$ & - \\
Shariah committee & $27-33$ & - \\
Qard & $34-36$ & -
\end{tabular}

The Shariah disclosure index was calculated using the following formula:

$$
\text { Shariah Disclosure Index }=\frac{\sum \text { Actual disclosure } \times 100}{\text { Total number of relevant items }}
$$

Based on the formula, the actual disclosure is the total number of Shariah items disclosed by a bank in its annual report, whereas the total number of relevant items is the total number of items on the index that are relevant to that specific bank. For example, for those banks that pay zakat, item No. 18, which is the reason for not paying zakat is not relevant to them. Therefore, the total relevant items is 35 (i.e. 36 items minus 1), as both mandatory and voluntary items are deemed relevant. This is because all categories listed above (Table 1) are relevant to Islamic banks, thus other than item No. 18, the remaining items are considered to be items that should be disclosed by the banks. Nevertheless, there has been a distinction between mandatory and voluntary items in the analyses of Shariah disclosure.

Two types of analyses were performed by this study: (i) each bank's extent of Shariah disclosure, which is based on overall disclosure and (ii) the extent of Shariah disclosure for each item.

\subsection{Method}

Watson (2015) considered quantitative research as a way of thinking about the world which involves deductive approach, measurement, analysis as well as conclusion. Rasinger (2013) outlined the flow of quantitative deductive approach, which is first based on theory and developing hypotheses, which are then either proven or disproven by the empirical results. Similarly, Holton and Burnett (2015) specified that the quantitative approach normally starts with a specific theory, which leads to hypotheses that are then measured quantitatively and evaluated according to established research procedures.

Therefore, it can be concluded that this study employs quantitative research as it framed a hypothesis based on Institutional theory. Furthermore, in order 
Amin, Ariffin, \& Fatima $\mid$ Shariah Disclosure Practices in Malaysian Islamic Banks using the Shariah Disclosure Index

to test this hypothesis, secondary data were collected from the annual reports using content analysis, specifically to determine the extent of Shariah disclosure of Islamic banks using the disclosure index that was developed, as explained above. Then, the study used rudimentary statistical analysis, in particular ratios and percentages as the measure of extent of Shariah disclosure.

\section{Results and Analysis}

\subsection{Results}

Table 2 presents the extent of mandatory and voluntary Shariah disclosure for each of the Islamic banks. The banks are ranked according to those that have the highest percentage of mandatory disclosure, followed by the highest percentage of voluntary disclosure. The total relevant items (TRI) are clearly indicated as the denominator under the column MTS/TRI (Table 2). Therefore, the percentage of disclosure is more accurate as it is based on a variable denominator, which is the total items specifically relevant to each Islamic bank. As these are mandatory items, they are deemed to be the minimum required disclosure.

Table 2. Extent of Mandatory and Voluntary Shariah Disclosure

\begin{tabular}{llcccr}
\hline Bank & \multicolumn{1}{c}{ Description } & MTS/TRI & MD (\%) & VTS & VD (\%) \\
\hline A & Domestic full-fledged Islamic & $26 / 27$ & 96.3 & 3 & 60.0 \\
B & Subsidiary of domestic bank & $26 / 27$ & 96.3 & 3 & 60.0 \\
C & Subsidiary of domestic bank & $26 / 27$ & 96.3 & 1 & 20.0 \\
D & Foreign full-fledged Islamic & $25 / 26$ & 96.2 & 2 & 40.0 \\
E & Subsidiary of foreign bank & $25 / 27$ & 92.6 & 3 & 60.0 \\
F & Subsidiary of domestic bank & $25 / 27$ & 92.6 & 0 & 0.0 \\
G & Subsidiary of foreign bank & $21 / 23$ & 91.3 & 3 & 60.0 \\
H & Subsidiary of domestic bank & $24 / 27$ & 88.9 & 2 & 40.0 \\
I & Subsidiary of domestic bank & $26 / 30$ & 86.7 & 0 & 0.0 \\
J & Subsidiary of domestic bank & $23 / 27$ & 85.2 & 3 & 60.0 \\
K & Subsidiary of domestic bank & $25 / 30$ & 83.3 & 2 & 40.0 \\
L & Subsidiary of domestic bank & $22 / 27$ & 81.5 & 0 & 0.0 \\
M & Domestic full-fledged Islamic & $23 / 30$ & 76.7 & 0 & 0.0 \\
N & Subsidiary of foreign bank & $17 / 23$ & 73.9 & 1 & 20.0 \\
O & Foreign full-fledged Islamic & $16 / 23$ & 69.6 & 0 & 0.0 \\
P & Foreign full-fledged Islamic & $15 / 23$ & 65.2 & 0 & 0.0 \\
\hline
\end{tabular}

Total mandatory items $=31$; Total voluntary items $=5$ as all items are deemed to apply to all Islamic banks

MTS = Total score of mandatory items $\mathrm{TRI}=$ Total relevant items

$\mathrm{MD}(\%)=$ Percentage of mandatory disclosure $\quad \mathrm{VTS}=$ Total score of voluntary items VD $(\%)=$ Percentage of voluntary items 
Overall, based on the average, Shariah disclosure of mandatory and voluntary items are approximately 86 percent and 29 percent, respectively. In Table 2, although the total mandatory items are 31, the maximum TRI is 30 items for Banks I, $\mathrm{K}$ and $\mathrm{M}$. As explained above, since Bank I is paying zakat, the "reason of not paying zakat" is not relevant to them. Banks A, B, C and D have the highest percentage of mandatory disclosure at $96 \%$. Banks $A$ and $B$ also rank high in terms of voluntary disclosure as they disclose 3 of the 5 voluntary items.

Upon further analysis, 7 banks have mandatory Shariah disclosure of above $90 \%$. The top 3, based on mandatory disclosure are domestic banks (Banks A, $B$ and $C$ ). This finding is conceivable as domestic banks are more likely to recognise the authority of BNM and comply with its guidelines. As for the foreign banks, they may also have to consider the disclosure requirements set by the parent and their home country. Nevertheless, 3 of the 7 banks that have above $90 \%$ disclosure of mandatory items, are foreign banks (Banks D, E and $\mathrm{G}$ ). Therefore, foreign banks also comply with the guidelines set by BNM. Furthermore, 3 of these banks are subsidiaries of domestic banks (Banks B, C and $F$ ) and 2 are subsidiaries of foreign banks (Banks $E$ and $G$ ). Thus, it is not only the full-fledged Islamic banks that consider Shariah disclosure to be important to their stakeholders. However, although these banks seem to be relatively high in terms of disclosing mandatory items, there are still banks, Bank $F$ in particular, that did not voluntarily disclose Shariah information.

It is interesting to find that the banks that have percentage of mandatory Shariah disclosure in the $80 \%$ range are all subsidiaries of domestic banks (Banks $\mathrm{H}-\mathrm{L}$ ). However, although quite high in terms of complying with BNM guidelines on Shariah disclosure, Banks I and $\mathrm{L}$ did not seem to have any voluntary Shariah disclosure.

Unfortunately, Bank $\mathrm{M}$, which is one of the domestic full-fledged Islamic banks only has a percentage of about $77 \%$ in terms of mandatory Shariah disclosure. Moreover, Banks $\mathrm{O}$ and $\mathrm{P}$, which have the lowest compliance in terms of mandatory Shariah disclosure, are both full-fledged Islamic banks. Furthermore, all 3 of these banks do not seem to have any voluntary Shariah disclosure. Hence, it could be of concern as these Islamic banks seem to be in need of much improvement in terms of Shariah disclosure.

Overall, based on the findings, 12 out of 16 Islamic banks have more than $80 \%$ Shariah disclosure. Even though $80 \%$ of disclosure seems high, mandatory items should have $100 \%$ compliance. This is because based on the Institutional Theory, coercive isomorphism highlighted that the pressure from BNM should have resulted in Islamic banks disclosing all relevant mandatory items. For 
Amin, Ariffin, \& Fatima $\mid$ Shariah Disclosure Practices in Malaysian Islamic Banks using the Shariah Disclosure Index

example, Bank A has 27 relevant mandatory items that should be disclosed. However, they only disclosed 26 items which is about $96.3 \%$ disclosure. The item that is not met by the bank is on gharamah (penalty) charges. In fact, all Islamic banks should disclose all mandatory items due to regulatory pressure under the Institutional Theory.

Moreover, among the 16 Islamic banks, 10 of them have disclosed at least one of the voluntary Shariah disclosure items as recommended by the AAOIFI standards. Hence, the results reveal that there are Islamic banks that disclose more than the mandatory Shariah disclosure items, as these disclosures are made voluntarily. Since transparency is promoted in Islam, customers may perceive these banks favourably for providing more useful information. However, one-third of the Islamic banks do not have voluntary Shariah disclosure at all. Therefore, similar to the disclosure of mandatory items, the disclosure of voluntary Shariah information could be improved.

In analysing each Shariah disclosure category, the financing, deposit, and investment category, totalling 11 items, is in Table 3. The first 2 items on the types and classification of financing into main Shariah are disclosed by all 16 Islamic banks. The next two items on compensation ( $t a^{\prime}$ widh) and penalty (gharamah) charges are disclosed by two and six Islamic banks, respectively. Even though, it may be that only these banks have this charge, as this is a mandatory disclosure required by BNM, the other Islamic banks should at least include a statement that they have no ta'widh and gharamah charges instead of remaining silent on the matter. For example, Bank B clearly states that "the bank does not charge gharamah for its financial facilities". Therefore, it is made transparent to the stakeholders that gharamah is not charged by Bank B, hence further disclosure would be irrelevant. If such a disclosure is not made, the stakeholders are left guessing as to whether an item is not relevant or it is case of non-disclosure.

The last 4 items listed in the table are basically on the restricted and unrestricted investments. Out of 4 items, one item (Item 9) is a mandatory BNM requirement; the other 3 items are AAOIFI guidelines, thus voluntary disclosure in Malaysia. In relation to Item 9, 75\% of Islamic banks classified the unrestricted investment account into the main Shariah contract.

In terms of voluntary items, half of the banks disclosed the statement of opening and closing balance of restricted investment and disclosed the distribution of unrestricted investment account, whereas 7 banks disclosed the sources of unrestricted investment account; however, none disclosed the method used to allocate the investment profit. Nevertheless, the voluntary 
disclosure indicates that there are Islamic banks which disclosed more than expected by BNM.

Table 4 lists the zakat and charity category. The findings show that none of the Islamic banks disclosed the opening and closing balance of zakat. This might be because this requirement is from AAOIFI guideline, thereby voluntary. Hence, Islamic banks are not pressured by BNM to disclose this information. In addition, out of 16 Islamic banks, only 11 Islamic banks pay zakat. These 11 banks disclose their zakat amount and responsibility of paying zakat, however, only 10 Islamic banks disclose the method applied in determining the zakat base. However, only 6 of these 11 Islamic banks reveal the amount of their zakat distribution to beneficiaries.

Table 3. Financing, Deposit, and Investment

\begin{tabular}{|c|c|c|c|}
\hline No & Shariah disclosure item & $\begin{array}{l}\text { Number of Islamic } \\
\text { banks with } \\
\text { Disclosures }\end{array}$ & $\begin{array}{c}\text { Total } \\
(\%)\end{array}$ \\
\hline & Financing & & \\
\hline 1. & $\begin{array}{l}\text { Types of financing (home, personal financing, etc.) } \\
\text { offered by the bank }\end{array}$ & 16 & 100 \\
\hline 2. & $\begin{array}{l}\text { Classification of financing into main Shariah contracts } \\
\text { (BBA, murabahah, etc.) }\end{array}$ & 16 & 100 \\
\hline 3. & $\begin{array}{l}\text { Ta'widh (compensation) charges for late payment } \\
\text { financing }\end{array}$ & 2 & 13 \\
\hline 4. & $\begin{array}{l}\text { Gharamah (penalty) charges for late payment financing } \\
\text { Deposit }\end{array}$ & 6 & 38 \\
\hline 5. & Type of Islamic deposit (saving, demand, etc.) & 16 & 100 \\
\hline 6. & $\begin{array}{l}\text { Classification of Islamic deposits into main Shariah } \\
\text { contract (wadiah, tawarruq) } \\
\text { Investment }\end{array}$ & 16 & 100 \\
\hline 7. & Opening and closing balance of restricted investment & 8 & 50 \\
\hline 8. & Sources of unrestricted investment account & 7 & 44 \\
\hline 9. & $\begin{array}{l}\text { Classification of unrestricted investment account into } \\
\text { main Shariah contract }\end{array}$ & 12 & 75 \\
\hline 10. & Profit sharing ratio of unrestricted investment account & 8 & 50 \\
\hline 11. & $\begin{array}{l}\text { Method used to allocate investment profit (separate vs. } \\
\text { pooling) }\end{array}$ & 0 & 0 \\
\hline
\end{tabular}

Items 1-11: Relevant to all Islamic banks ( $\mathrm{N}=16)$ 
Amin, Ariffin, \& Fatima $\mid$ Shariah Disclosure Practices in Malaysian Islamic Banks using the Shariah Disclosure Index

Table 4. Zakat and Charity

\begin{tabular}{clcc}
\hline No & \multicolumn{1}{c}{ Shariah disclosure item } & $\begin{array}{c}\text { Number of Islamic } \\
\text { banks with Disclosures }\end{array}$ & $\begin{array}{c}\text { Total } \\
\text { (\%) }\end{array}$ \\
\hline 1. & Opening and closing balance of zakat fund & 0 & 0 \\
2. & Amount of zakat payable & 11 & 100 \\
3. & Amount of zakat distributed & 6 & 45 \\
4. & Bank's responsibility to pay zakat & 11 & 100 \\
5. & Method applied in determining zakat base & 10 & 91 \\
6. & Beneficiaries of zakat fund & 7 & 64 \\
7. & Reason for Islamic bank for not paying zakat & 4 & 80 \\
8. & Sources of donations / charities fund & 13 & 81 \\
9. & Usage of donations /charities fund & 13 & 81
\end{tabular}

Items 1-6: Relevant to 11 Islamic banks that pay zakat $(\mathrm{N}=11)$

Item 7: Relevant to 5 Islamic banks that do not pay zakat ( $N=5)$

Items 8-9: Relevant to all Islamic banks ( $\mathrm{N}=16)$

As for the 5 Islamic banks that do not pay zakat, only 4 Islamic banks disclose that it is not the banks' responsibility to pay zakat as it is deemed to be the responsibility of individual depositors. One of the Islamic banks did not make any statement and was silent about zakat. Moreover, from the analysis, only 10 Islamic banks disclosed the sources and usage of donation funds. This information should be disclosed by the Islamic banks as stakeholders would want to know the source of charities fund, the amount collected and its usage.

Since all Islamic banks should operate within the boundaries of the Shariah, it is essential to be transparent if there is any income from non-Shariah compliant activity. Table 5 reveals that the majority of Islamic banks do disclose items related to non-Shariah compliance, i.e. the nature and amount of Shariah non-compliance income, as well as rectification process and control measures to avoid recurrence of the activity. The relatively high disclosure may be because these items are mandatorily required by BNM. The Islamic banks should at least include a statement which negates Shariah noncompliance activities during the year. 
Amin, Ariffin, \& Fatima $\mid$ Shariah Disclosure Practices in Malaysian Islamic Banks using the Shariah Disclosure Index

Table 5. Non-Shariah Compliant Activities

\begin{tabular}{clcc}
\hline & Shariah disclosure item & $\begin{array}{c}\text { Number of Islamic } \\
\text { banks with } \\
\text { Disclosures }\end{array}$ & $\begin{array}{c}\text { Total } \\
\text { (\%) }\end{array}$ \\
\hline 1. Nature of Shariah non-compliance activity & 13 & 81 \\
2. Amount of Shar'ah non-compliance income & 14 & 88 \\
3. Number of Shariah non-compliance activities which & 13 & 81 \\
4. $\quad$ Rectification process to avoid recurrence & 13 & 81 \\
5. $\quad$ Control measure to avoid recurrence & 13 & 81 \\
6. & Disposal of prohibited earnings to charitable causes & 16 & 100 \\
\hline
\end{tabular}

Item1-6: Relevant to all Islamic banks ( $\mathrm{N}=16)$

Table 6. Shariah Committee

\begin{tabular}{clcc}
\hline No & Shariah disclosure item & $\begin{array}{c}\text { Number of } \\
\text { Islamic banks } \\
\text { with Disclosures }\end{array}$ & $\begin{array}{c}\text { Total } \\
\text { (\%) }\end{array}$ \\
\hline 1. & $\begin{array}{l}\text { Shariah committee member's signature on Shariah } \\
\text { committee report }\end{array}$ & 16 & 100 \\
2. Purpose of Shariah committee engagement & 16 & 100 \\
3. Nature of work performed by Shariah committee & 16 & 100 \\
4. Management responsibility in ensuring Shariah & 16 & 100 \\
& compliance & 16 & 100 \\
5. Shariah committee endorsement on Shariah compliance & in contract and document & 16 & 100 \\
6. Shariah committee member's remuneration & 16 & 100 \\
7. Shariah committee member's qualification & &
\end{tabular}

Items 1-7: Relevant to all Islamic banks ( $\mathrm{N}=16)$

Table 6 lists items disclosed in the Shariah committee report related to Shariah governance framework. The findings show that all Islamic banks disclosed the Shariah committee member's signature, statement on the purpose of Shariah committee engagement, nature of work performed by the Shariah committee, management responsibility in ensuring Shariah compliance, and Shariah committee endorsement on Shariah compliance in contract and document. All banks also disclosed the remuneration and qualification of their Shariah committee members.

Qard is an interest-free loan. Table 7 lists the Shariah disclosure items related to qard. After analysing the annual reports, only 4 out of the 16 Islamic banks disclosed the details on qard funds as only these banks offer qard. All 4 banks disclosed the usage of qard fund, but only one of them did not disclose the opening balance, closing balance and sources of qard fund. 
Amin, Ariffin, \& Fatima $\mid$ Shariah Disclosure Practices in Malaysian Islamic Banks using the Shariah Disclosure Index

Table 7. Qard

\begin{tabular}{clcc}
\hline No & Shariah disclosure item & $\begin{array}{c}\text { Number of Islamic } \\
\text { bank with } \\
\text { Disclosures }\end{array}$ & $\begin{array}{c}\text { Total } \\
\text { (\%) }\end{array}$ \\
\hline 1. & Opening and closing balance of qard & 3 & 75 \\
2. & Sources of qard fund & 3 & 75 \\
3. & Usage of qard fund & 4 & 100 \\
\hline Items 1-3: Relevant to 4 Islamic banks (N=4) & &
\end{tabular}

\subsection{Analysis}

Based on the overall analysis, the majority of items are disclosed by all Islamic banks. However, none of the banks had 100\% compliance, even on mandatory items. Therefore, the hypothesis that there would be high disclosure amongst Islamic banks due to coercive isomorphism and greater accountability, is rejected. These findings are generally in line with prior studies (Wan Abdullah et al., 2013; Ramli et al., 2015), which concluded that Islamic banks in Malaysia could improve on their Shariah disclosure. Specifically, prior studies such as Wan Abdullah et al. (2013) and Ramli et al. (2014) found that there is lack of disclosure on Shariah items among Islamic banks in Malaysia. None of them had $100 \%$ compliance. The study suggested for higher disclosure to demonstrate greater accountability. In fact, all Islamic banks should disclose all mandatory items due to regulatory pressure under the Institutional Theory.

Furthermore, Paino et al. (2011) found no significant difference in the level of Shariah disclosure among Islamic banks in Malaysia, due to the items being required by BNM. However, this study found differences in percentages of mandatory and voluntary disclosure amongst the Islamic banks, hence inconsistent with Paino et al.'s (2011) findings. Nevertheless, the Islamic banks were all consistent on disclosing all the items on Shariah committee, thus attaining 100\% disclosure. In fact, Islamic banks should ensure that all mandatory disclosure items required by BNM are disclosed, if not, these banks may face hefty penalties.

Based on the entire analysis for each item, it shows that most of the items were disclosed by all Islamic banks. The obvious findings on the category of Shariah committee was that all items in that category 
Amin, Ariffin, \& Fatima | Shariah Disclosure Practices in Malaysian Islamic Banks using the Shariah Disclosure Index

showed $100 \%$ score which means that all Islamic banks disclosed those items related to Shariah committee. This finding shows that there is no variation in the extent of disclosure made by the Islamic banks in relation to this category. This finding is consistent with the findings of Paino et al. (2011) that there is no significant difference in the level of Shariah disclosure among Islamic banks in Malaysia.

\section{Conclusion and Recommendation}

\subsection{Conclussion}

This study measured the compliance level of Shariah disclosure using a disclosure index developed from BNM and AAOIFI guidelines for mandatory and voluntary disclosure, respectively. As mentioned above, the findings contradict Institutional theory as none of the Islamic banks had $100 \%$ disclosure, even on the mandatory items, although there should be coercive pressure from BNM. In fact, on average, the disclosure of mandatory items was about 86 percent, hence could be further improved by 14 percent. Naturally, disclosure of the voluntary items was much lower at 29 percent.

Specifically, there was lack of disclosure on gharamah and ta'widh charges. According to "Guidelines on Late Payment Charges for Islamic Financial Institutions", the Shariah does not allow gharamah to be recognised as a source of income for the Islamic banks, therefore all gharamah amounts must be channelled to charitable organisations. Therefore, Islamic banks are required to disclose the use of gharamah amount in the notes to the accounts for 'Sources and usage of donations or charities fund'. In addition, Muslim stakeholders would deem $t a^{\prime}$ widh charges as important. Thus, banks that do not charge gharamah or ta'widh charges should clearly mention this to their stakeholders. Moreover, stakeholders may be interested in the beneficiaries of zakat funds, hence this information should be disclosed in the annual reports. This will lead to these Islamic banks discharging their accountability to their stakeholders, and society whilst upholding Shariah principles. Other findings show that there are some banks which disclose the voluntary items as highlighted by the AAOIFI standards. 
Amin, Ariffin, \& Fatima $\mid$ Shariah Disclosure Practices in Malaysian Islamic Banks using the Shariah Disclosure Index

\subsection{Recommendation}

The study suggests that BNM as a regulator should put an effort in determining the reasons behind the non-compliance of Shariah mandatory disclosure requirements by Islamic banks. Regulators should be apprehensive that none of the Islamic banks had 100\% compliance, even on mandatory items. Thus, further investigation is warranted. In fact, it is of concern that a few full-fledged Islamic banks ranked relatively low in terms of mandatory compliance. On the contrary, some banks are voluntarily disclosing items recommended by AAOIFI. These banks may perceive the information to be useful to their stakeholders; therefore, BNM may consider including these items in their financial reporting guidelines for Islamic banking institutions, in future.

\subsection{Limitations of the Study and Suggestions for Future Research}

Although this study meets its objectives and provides useful findings, there are some limitations that could be considered by future studies. Firstly, since this study's sample is the population of Islamic banks in Malaysia, the findings is not generalisable to other Islamic financial institutions (IFIs) in Malaysia. Therefore, future research could conduct a similar study on other IFIs, and in other countries. Moreover, this study has relied on content analysis of secondary data. Hence, future studies could conduct interviews to obtain clarification and gain deeper insight on Shariah disclosure in IFIs. 
Amin, Ariffin, \& Fatima $\mid$ Shariah Disclosure Practices in Malaysian Islamic Banks using the Shariah Disclosure Index

\section{References}

Accounting and Auditing Organization for Islamic Financial Institutions (AAOIFI) (1991). Shariah standard.

Adina, P. \& Ion, P. (2008). Aspects regarding corporate mandatory and voluntary disclosure. Annals of the University of Oradea: Economic Science, 3(1), 1407-1411.

Ahmad. N. S. M \& Daw, A. S. D. B. (2015). Compliance with AAOIFI guidelines in general presentation and disclosure by Libyan Islamic banks. World Journal of Entrepreneurship, Management and Sustainable Development, 11(2), 90-99.

Ajili, H., \& Bouri, A. (2017). Comparative study between IFRS and AAOIFI disclosure compliance: evidence from Islamic banks in Gulf CoOperation Council countries. Journal of Financial Reporting and Accounting, 15(3), 269-292.

Ariff, M. (1988). Islamic banking. Asian-Pacific Economic Literature, 2(2), 4662.

Ashraf, M. \& Lahsasna, A. (2017). Proposal for a new Sharīaah risk rating approach for Islamic banks. ISRA International Journal of Islamic Finance, 9(1), 87-94.

Bank Negara Malaysia (BNM) (2010). Shariah Governance Framework. Kuala Lumpur: Bank Negara Malaysia.

Bank Negara Malaysia (2016), List of Licensed Financial Institutions in Malaysia. Kuala Lumpur: Bank Negara Malaysia.

Bank Negara Malaysia (2016). Financial Reporting for Islamic Banking Institutions (GP8-i). Kuala Lumpur: Bank Negara Malaysia.

Bank Negara Malaysia (2019). Financial Reporting for Islamic Banking Institutions. Kuala Lumpur: Bank Negara Malaysia.

Bank Negara Malaysia (BNM) (2019). Shariah Governance Policy Document. Kuala Lumpur: Bank Negara Malaysia.

Bank Negara Malaysia (BNM) (2019). Islamic Financial Service Act (IFSA). Kuala Lumpur: Bank Negara Malaysia

Baydoun, N. \& Willett, R. (2000). Islamic corporate reports. Abacus, 36(1), 7190.

Carpenter, V. L., \& Feroz, E. H. (2001). Institutional theory and accounting rule choice: an analysis of four US state governments' decisions to adopt generally accepted accounting principles. Accounting, Organizations and Society, 26(7), 565-596. 
Amin, Ariffin, \& Fatima $\mid$ Shariah Disclosure Practices in Malaysian Islamic Banks using the Shariah Disclosure Index

Frolov, M. (2007). Why do we need mandated rules of public disclosure for banks? Journal of Banking Regulation, 8(2), 177-191.

Haniffa, R., \& Hudaib, M. A. (2002). A theoretical framework for the development of the Islamic perspective of accounting. Accounting, Commerce and Finance: The Islamic Perspective Journal, 6(1/2), 1-71.

Haniffa, R. \& Hudaib, M. (2007). Exploring the ethical identity of Islamic banks via communication in annual reports. Journal of Business Ethics, 76(1), 97-116.

Healy, P. M., \& Palepu, K. G. (2001). Information asymmetry, corporate disclosure, and the capital markets: A review of the empirical disclosure literature. Journal of accounting and economics, 31(1), 405-440.

Holton, E. F., \& Burnett, M. F. (2005). The basics of quantitative research. Research in organizations: Foundations and methods of inquiry, 29-44.

Huang, R. (2006), Private information trading and enhanced accounting disclosure of bank stocks, The World Bank, Retrieved on $7^{\text {th }}$ April 2016. Retrieved from http://docplayer.net

/12656825-Private-information-trading-and-enhanced-accountingdisclosure-of-bank-stocks.html.

International Accounting Standards Board (2018), Conceptual Framework for Financial Reporting, London: International Accounting Standards Board.

Iqbal, M., Ahmad, A., \& Khan, T. (1998). Challenges facing Islamic banking. Islamic Development Bank, Islamic Research and Training Institute, Occasional Paper, (1).

Islam, R., Ahmed, S. \& Abdul Razak, D. (2015). Identifying the gaps between customer expectations and perceptions on service quality dimensions of Islamic banks in Malaysia. International Journal of Quality and Service Sciences, 7(4), 424-441.

Maali, B., Casson, P., \& Napier, C. (2006). Social reporting by Islamic banks. Abacus, 42(2), 266-289.

Malaysia International Islamic Financial Centre (2014). Shariah Compliance in All Matters. The Priority of a Robust Islamic Finance Ecosystem.

Paino, H., Bahari, A. B., \& Bakar, R. A. (2011). Shariah, social responsibilities and corporate governance of the Islamic banks in Malaysia. European Journal of Social Sciences, 23(3), 382-391.

Quran 4:86, Oxford Worlds Classic edition.

International Journal of Islamic Economics and Finance (IJIEF), 4(SI), 63-86 84 
Amin, Ariffin, \& Fatima $\mid$ Shariah Disclosure Practices in Malaysian Islamic Banks using the Shariah Disclosure Index

Rahaman, A. S., Lawrence, S., \& Roper, J. (2004). Social and environmental reporting at the VRA: institutionalised legitimacy or legitimation crisis? Critical Perspectives on Accounting, 15(1), 35-56.

Ramli, N. M., Majid, A. S. A., Muhamed, N. A., \& Yaakub, N. A. (2015). Shariah Governance Disclosure Index and Institutional Ownership of Islamic Financial Institutions in Malaysia. Journal of Islamic Finance and Business Research, 3(1). 1-13.

Rasinger, S. M. (2013). Quantitative research in linguistics: An introduction. A\&C Black.

Sarea, A. M., \& Hanefah, M. M. (2013). Adoption of AAOIFI accounting standards by Islamic banks of Bahrain. Journal of Financial Reporting and Accounting, 11(2), 131-142.

Shatnawi, Z. S \& Al-bataineh, I. M (2013). Commitment extent by Jordan Islamic bank with AAOIFI's accounting and auditing standards. Interdisciplinary Journal of Contemporary Research in business, 5(4), 661-676.

Siddiqi, M. N. (2006). Islamic banking and finance in theory and practice: A survey of state of the art. Islamic Economic Studies, 13(2), 1-48.

Sole, J. A. (2007). Introducing Islamic banks into Conventional banking systems. IMF Working Papers, 1-26.

Ullah, H. (2014). Shariah compliance in Islamic banking: An empirical study on selected Islamic banks in Bangladesh. International Journal of Islamic and Middle Eastern Finance and Management, 7(2), 182-199.

Verrecchia, R. E. (2001). Essays on disclosure. Journal of accounting and economics, 32(1), 97-180.

Wan Abdullah, W. A., Percy, M., \& Stewart, J. (2013). Shariah disclosures in Malaysian and Indonesian Islamic banks: The Shariah governance system. Journal of Islamic Accounting and Business Research, 4(2), 100-131.

Watson, R. (2015). Quantitative research. Nursing Standard, 29(31).

Wang, P., Che, F., Fan, S., \& Gu, C. (2014). Ownership governance, institutional pressures and circular economy accounting information disclosure: An Institutional Theory and corporate governance theory perspective. Chinese Management Studies, 8(3), 487-501. 
Amin, Ariffin, \& Fatima $\mid$ Shariah Disclosure Practices in Malaysian Islamic Banks using the Shariah Disclosure Index

This page is intentionally left blank.

International Journal of Islamic Economics and Finance (IJIEF), 4(SI), 63-86 86 